\title{
PENGARUH LAYANAN INFORMASI TERHADAP \\ PERENCANAAN KARIR REMAJA DI KELURAHAN DALAN \\ LIDANG KECAMATAN PANYABUNGAN KABUPATEN MANDAILING NATAL
}

\author{
${ }^{1}$ Ririn Mayani Ulfa, ${ }^{2}$ Nengsih, ${ }^{3}$ Khairina Afni \\ Mahasiswa STKIP Budidaya Binjai \\ 1e-mail : (ririnulfa5376@ gmail.com) \\ Dosen STKIP Budidaya Binjai \\ ²e-mail : (tanjungnengsih13@gmail.com) Dosen \\ STKIP Budidaya Binjai \\ 3e-mail : (khairinaafni89@gmail.com)
}

\begin{abstract}
ABSTRAK
Tujuan penelitian ini adalah untuk mengetahui pengaruh Layanan Informasi terhadap Perencanaan Karir Remaja diKelurahan Dalan Lidang Kecamatan Panyabungan Kabupaten Mandailing Natal. Jenis penelitian yang digunakan dalam penelitian ini adalah penelitian Kuantitatif dengan metode Quasi Eksperiment. Instrumen yang digunakan adalah dengan menyebarkan angket pada seluruh sampel sebagai bahan masukan untuk mengetahui situasi yang sebenarnya di kelurahan Dalan Lidang, dan analisis datanya menggunakan Uji T. Dari hasil uji hipotesis yaitu uji t maka diperoleh nilai Pretes Perencanaan Karir Remaja mempunyai rata-rata 77,53 dan standard deviasi 7,736, Sedangkan postes mempunyai rata- rata 81,57 dan standard deviasi 6,668 sehingga diperoleh t hitung 67,001. $\mathrm{t}$ hitung $>\mathrm{t}$ tabel yaitu 67,001 > 2,045, sehingga diambil suatu kesimpulan bahwa terdapat pengaruh Layanan Informasi Terhadap Perencanaan Karir Remaja di Kelurahan Dalan Lidang Kecamatan Panyabungan Kabupaten Mandailing Natal.
\end{abstract}

Kata Kunci : Layanan Informasi, Perencanaan Karir

\begin{abstract}
The purpose of this study was to determine the effect of Information Services on Youth Career Planning in Dalan Lidang Subdistrict, Panyabungan District, Mandailing Natal Regency. This type of research used in this research is quantitative research with the Quasi Experiment method. The instrument used was to distribute questionnaires to all samples as input to find out the actual situation in the Dalan Lidang village, and the data analysis used the T test. From the results of the hypothesis test, namely the $t$ test, it was obtained that the pretest value for Adolescent Career Planning had an average of 77, 53 and a standard deviation of 7,736, while post-test has an average of 81.57 and a standard deviation of 6.668 so that the $t$ count is 67.001. $t$ count $>t$ table is 67,001 >2,045, so it can be concluded that there is an influence of Information Services on Adolescent Career Planning in Dalan Lidang Village, Panyabungan District, Mandailing Natal Regency.
\end{abstract}

Keywords: Information Services, career planning. 


\section{PENDAHULUAN}

Perkembangan teknologi terus berkembang seiring dengan perkembangan dalam dunia pendidikan yang terus menuntut peserta didik dalam hal ini remaja untuk dapat mengikuti perkembangan tersebut dengan berbagai macam permasalahan yang ada seperti masalah pribadi, sosial, pemilihan dunia kerja, salah memilih jurusan dan rasa percaya diri yang kurang, serta merencanakan karir untuk masa yang akan datang sehingga dapat membuat remaja merasa bingung untuk meraih kesuksesan dalam kehidupannya.

Anak remaja akan selalu dihadapkan dengan perubahan yang terus berkembang dengan pesat. Hurlock (2009:221) menjelaskan "masa remaja merupakan masa yang sangat berhubungan pada penentuan kehidupan di masa depan". Situasi dalam pendidikan pada saat ini sudah cukup kompleks. Kecenderungan yang muncul di permukaan remaja pada saat ini, ditunjang oleh laju perkembangan teknologi dan arus gelombang kehidupan global yang sulit atau tidak mungkin untuk di bendung. Dalam konteks pembela- jaran, gejala negatif yang tampak adalah kurang mandiri pada remaja yang tidak mampu untuk menentukan arah cita-cita yang akan diraih, mengakibatkan tidak dapat merencanakan karirnya setelah selesai dari sekolah menengah atas.

Perencanaan karir merupakan suatu hal yang hendaknya dilakukan oleh remaja sedini mungkin. Perencanaan mengenai karier sangat diperlukan mengingat remaja sudah mulai memikirkan masa depan. Super (seperti dikutip Nengsih, 2019:57) menjelaskan bahwa "perencanaan karier dapat mengukur tingkat pemahaman individu terhadap macam-macam jenis pencarian informasi dan mengukur tingkat pemahaman mereka tentang berbagai aspek pekerjaan". Setidaknya remaja memiliki gambaran dan rencana yang baik untuk masa depan yang sesuai yang diinginkan.

Salah satu bentuk layanan yang harus dilakukan dalam mengatasi permasalahan karir ini adalah dengan menyelenggarakan salah satu layanan dan bimbingan konseling yaitu layanan informasi.

Masa transisi yang dialami para remaja belum sanggup berperan sebagai orang dewasa, tetapi enggan jika disebut bahwa dia disebut anak-anak. Masa transisi yang dialami remaja ini seringkali menghadapkan individu yang bersangkutan kepada situasi yang membingungkan di satu pihak ia harus bertingkah laku seperti orang dewasa. Situasi yang menimbulkan konflik seperti ini menyebabkan perilaku aneh, bila tidak terkontrol dapat mengakibatkan kenakalan remaja, apalagi remaja yang sedang mengikuti pendidikan di sekolah.dapat mengakibatkan gagalnya dalam mengikuti mata pelajaran tertentu. Oleh karena itu banyak remaja atau remaja berangkat dari rumah pergi kesekolah, namun tidak sampai ke sekolah.

Pada masa remaja banyak kebutuhan yang ingin diperoleh, peranan konselor dan orangtua sangat penting, karena kebutuhan mereka harus dipenuhi, seperti kebutuhan akan kasih sayang, kebutuhan terhadap sandangpangan dan kebutuhan aktualisasi diri. Apabila keadaan ekonomi, pengetahuan dan pemahaman orangtua terhadap kebutuhankebutuhan tersebut kurang di dukung akan terjadi kenakalan pada remaja itu sendiri yang dapat menjerumuskan pada tindakan amoral, seperti suka bolos dari sekolah, berkelahi dan merusak sarana yang ada. 
Bimbingan dan konseling juga membantu dalam rangka mengenal lingkungan sosialnya, seperti lingkungan rumah, lingkungan sekolah dan lingkungan masyarakat serta lingkungan yang lebih luas dan diharapkan dapat menunjang sebagai manfaat bagi remaja dalam pengembangan diri secara mantap dan berkelanjutan. Menurut M.Luddin ( 2012:6) "Konseling adalah proses pemberian bantuan yang dilakukan melalui wawancara dan teknik pengubahan tingkah laku lainnya oleh seorang ahli (konselor) kepada individu- individu yang sedang mengalami masalah

(klien) yang bermuara teratasinya masalah yang dihadapi oleh klien."

Lingkungan di sekolah hendaknya menyediakan pelayanan serta bimbi- ngan kepada remaja agar dapat memberikan pengertian dan pembinaan sehingga dapat membantu menyelesaikan permasalahan yang dihadapi remaja, layanan informasi yaitu layanan bimbingan dan konseling yang memungkinkan peserta didik bisa menerima dan memahami berbagai informasi, oleh karena itu layanan informasi merupakan salah satu yang dipergunakan untuk membantu remaja untuk memahami dirinya sendiri dan dapat pemahaman terhadap orang lain dan mengembangkan pola kehidupan sebagai pelajar, anggota keluarga, dan masyarakat, pemahaman yang diperoleh peserta didik melalui layanan informasi di gunakan sebagai bahan acuan dalam kegiatan dan prestasi belajar, di samping itu layanan informasi juga memperluas lingkup informasi seperti perencanaan karir, memilih jurusan yang sesuai dengan kemampuan, penampilan pribadi, keterampilan sosial, baik dalam lingkungan sekolah dan dalam masyarakat, dan keluarga.

Proses layanan informasi dilakukan secara individual ataupun kelompok, dimana pemecahan masalah dalam proses konseling dilakukan dengan wawancara atau diskusi antara klien dengan konselor, seperti yang dikatakan Walgito (2005:7) "Konseling adalah bantuan yang diberikan kepada individu dalam memecahkan masalah kehidupannya dengan wawancara dan dengan cara yang sesuai dengan keadaan yang dihadapi individu untuk mencapai kesejahteraan hidupnya".

Berdasarkan hasil wawancara dengan Bapak Ahmad Dahri Nasution, S.H., pada tanggal 22 Juni 2020 ditemukan permasalahan di Kelurahan Dalan Lidang Kecamatan Panyabungan yaitu : 1) Masih ada remaja yang belum mengetahui informasi tentang diri nya sendiri, baik minat, bakat, kemampuan, potensi yang dimiliki. 2) Masih banyak remaja yang belum bisa memutuskan arah karir mereka, para remaja mengaku kurangnya wawasan dan informasi tentang karir yang mereka dapatkan sehingga remaja merasa bingung dengan citacita mereka sendiri. 3) Kurang mengetahui informasi mengenai pendidikan lanjutan dan keahlian yang diperlukan dalam satu bidang pekerjaan, serta tidak mengetahui bentukbentuk karir yang akan berkembang dan diperlukan dimasa yang akan datang.

Layanan informasi adalah layanan bimbingan konseling yang memungkinkan remaja menerima dan memahami berbagai informasi (seperti informasi pendidikan dan informasi jabatan) yang dapat digunakan sebagai bahan pertimbangan dan pengambilan keputusan untuk kepentingan remaja. Dalam hal ini informasi yang diberikan adalah informasi tentang perencanaan karir.

Menurut Prayitno (2010:271) ada tiga alasan utama mengapa pemberian informasi perlu diselenggarakan yaitu Pertama, membekali individu dengan berbagai pengetahuan tentang lingkungan yang 
diperlukan untuk memecahkan masalah yang dihadapi berkenaan dengan lingkungan sekitar, pendidikan, jabatan, maupun sosial budaya. Kedua, memungkinkan individu dapat menentukan arah hidupnya kemana dia ingin pergi. Ketiga, setiap individu adalah unik. Keunikan itu akan membawakan pola-pola pengambilan keputusan dan bertindak berbeda- beda disesuaikan dengan aspek-aspek kepribadian masing-masing individu. Layanan informasi karir perlu diberikan kepada remaja untuk menyaring serta menyeleksi potensi yang dimiliki oleh para remaja dalam menentukan pilihannya untuk mewujudkan dirinya pada pekerjaan atau karir yang akan ditempuh dikemudian hari.

Berdasarkan latar belakang diatas, maka penulis tertarik untuk meneliti tentang "Pengaruh Layanan Informasi Terhadap Perencanaan Karir Remaja di Kelurahan Dalan Lidang Kecamatan Panyabungan Kabupaten Mandailing Natal".

\section{METODOLOGI PENELITIAN}

Jenis penelitian ini adalah penelitian eksperimen semu (quasi experiment). Desain penelitian yang digunakan dalam penelitian ini adalah one group pretest post test design. Populasi penelitian adalah seluruh remaja di Kelurahan Dalan Lidang Kecamatan Panyabungan Kabupaten Mandailing Natal yang berjumlah 30 orang remaja. Sampel penelitian seluruh dari populasi remaja. Alat pengumpulan data menggunakan angket.

\section{HASIL DAN PEMBAHASAN}

\section{A. Hasil Penelitian}

\section{Deskripsi Data}

Pada bab ini diuraikan mengenai pelaksanaan penelitian yang dimulai dengan menyebarkan angket Perencanaan Karir yang terdiri dari 30 item. Angket ini diberikan

kepada 30 orang remaja yang menjadi sampel
Tabel 1. Hasil Perhitungan Statistik Pretest Perencanaan Karir

Pretest

\begin{tabular}{llrrrr}
\hline & 62 & 1 & 3,2 & 3,3 & 3,3 \\
\cline { 2 - 6 } & 64 & 1 & 3,2 & 3,3 & 6,7 \\
\cline { 2 - 6 } & 66 & 1 & 3,2 & 3,3 & 10,0 \\
\cline { 2 - 6 } & 68 & 3 & 9,7 & 10,0 & 20,0 \\
\cline { 2 - 6 } & 70 & 3 & 9,7 & 10,0 & 30,0 \\
\cline { 2 - 6 } valıa & 74 & 2 & 6,5 & 6,7 & 36,7 \\
\cline { 2 - 6 } & 78 & 3 & 9,7 & 10,0 & 46,7 \\
\cline { 2 - 6 } & 79 & 1 & 3,2 & 3,3 & 50,0 \\
\cline { 2 - 6 } & 80 & 2 & 6,5 & 6,7 & 56,7 \\
\cline { 2 - 6 } & 82 & 4 & 12,9 & 13,3 & 70,0 \\
\cline { 2 - 6 } & 84 & 3 & 9,7 & 10,0 & 80,0 \\
\cline { 2 - 6 } & 86 & 5 & 16,1 & 16,7 & 96,7 \\
\cline { 2 - 6 } & Total & 30 & 96,8 & 100,0 & \\
\hline Missing & System & 1 & 3,2 & & \\
\hline Total & \multicolumn{5}{c}{100,0} \\
\hline
\end{tabular}


dalam penelitian ini yang telah dijelaskan pada bab 3. Angket pada penelitian sudah diuji kevalidan dan reliabilitasnya dicantumkan pada lampiran 3

Data yang akan didiskusikan terdiri dari data angket Perencanaan Karir yang diperoleh dari hasil pretes dan postes dengan jumlah 26 item dibagikan kepada 30 orang remaja peserta layanan, sebagai sampel penelitian dengan menggunakan skala Likert. Jenis penelitian ini adalah penelitian kuantitatif dengan menggunakan teknik Quasi Experiment (Eksperimen Semu), yaitu penelitian yang tidak menggunakan kelas Kontrol.

\section{Data Pretes Perencanaan Karir}

Dari pemeriksaan yang telah dilakukan terhadap data, maka seluruh data layak diolah serta dianalisis. Berikut ini ditampilkan perhitungan frekuensi statistik dasar data pretest Perencanaan Karir, dapat dilihat pada tabel 1 berikut.
Dari tabel 1 maka dapat diperoleh data Pretes Perencanaan Karir dengan frekuensi jawaban remaja paling rendah 62 dan paling tinggi 89 dan jawaban yang paling banyak pada rentang interval 86 berjumlah 5 orang remaja. Selanjutnya dapat dilihat pada tabel frekuensi berikut

Tabel 2 Tabel Frekuensi Pretes Perencanaan Karir

\begin{tabular}{lrr}
\multicolumn{2}{c}{ Pretest } \\
\hline \multirow{2}{*}{$\mathrm{N}$} & Valid & 30 \\
\cline { 2 - 3 } & Missing & 1 \\
\hline Mean & 77,53 \\
\hline Median & 79,50 \\
\hline Std. Deviation & 7,736 \\
\hline Variance & 59,844 \\
\hline Minimum & 62 \\
\hline Maximum & 89 \\
\hline Sum & 2326 \\
\hline
\end{tabular}

Dari tabel 2 diperoleh data perhitungan statistik tentang Pretes Perencanaan Karir pada remaja di Kelurahan Dalan Lidang Kecamatan Panyabungan Kabupaten Mandailing Natal, sebanyak 30 orang dengan jumlah 26 item. Jumlah total dari skor Pretes $=\mathbf{2 3 2 6}$, dengan skor tertinggi 89 dan skor terendah 62 . Perhitungan mean $=77,53$, median 79,50, 
Standar deviasi $=7,736$. Dari data perhitungan statistik di atas dapat dibuat histogram sebagai berikut :

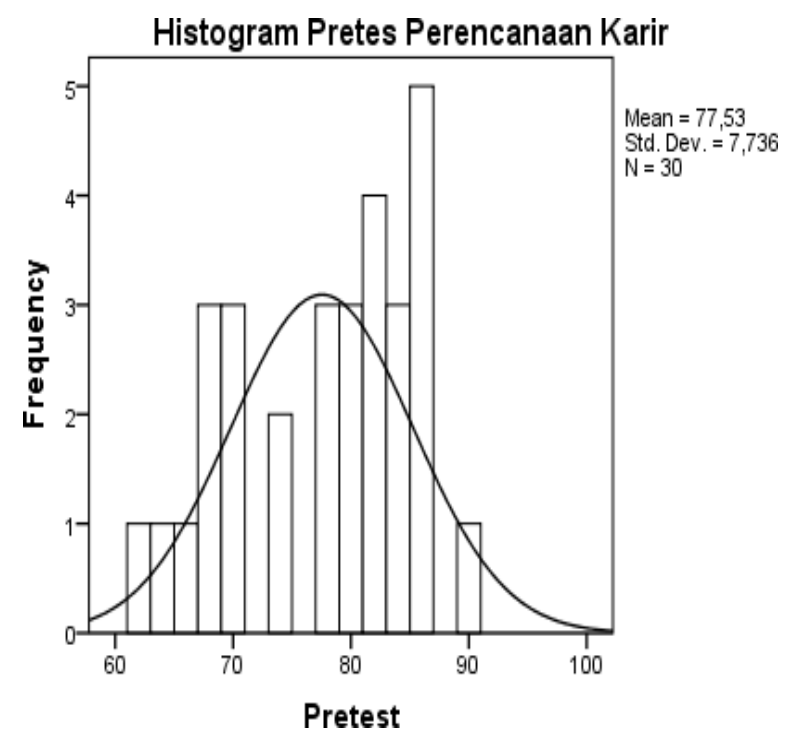

Gambar 1 Histogram Pretes Perencanaan Karir

Dari histogram pada gambar 1 dapat diketahui bahwa data berdistribusi normal, karena sebahagian diagram batang berada dibawah kurva normal, sehingga dapat dikatakan data berditribusi normal.

\section{Data Postes Perencanaan Karir}

Dari pemeriksaan yang telah dilakukan terhadap data, maka seluruh data layak diolah serta dianalisis. Berikut ini ditampilkan perhitungan frekuensi statistik dasar data Postes Perencanaan Karir Remaja, dapat dilihat pada tabel 3 berikut.

Tabel 3 Tabel Frekuensi Postes Perencanaan Karir

\begin{tabular}{|c|c|c|c|c|c|}
\hline \multicolumn{6}{|c|}{ Posttest } \\
\hline & & $\begin{array}{l}\text { Freq } \\
\text { uen } \\
\text { cy }\end{array}$ & $\begin{array}{c}\text { Perce } \\
\text { nt }\end{array}$ & $\begin{array}{c}\text { Valid } \\
\text { Perce } \\
\text { nt }\end{array}$ & $\begin{array}{c}\text { Cumula } \\
\text { tive } \\
\text { Percent }\end{array}$ \\
\hline \multirow{10}{*}{ Valid } & 67 & 1 & 3,2 & 3,3 & 3,3 \\
\hline & 69 & 1 & 3,2 & 3,3 & 6,7 \\
\hline & 73 & 2 & 6,5 & 6,7 & 13,3 \\
\hline & 74 & 1 & 3,2 & 3,3 & 16,7 \\
\hline & 75 & 2 & 6,5 & 6,7 & 23,3 \\
\hline & 76 & 2 & 6,5 & 6,7 & 30,0 \\
\hline & 78 & 1 & 3,2 & 3,3 & 33,3 \\
\hline & 80 & 1 & 3,2 & 3,3 & 36,7 \\
\hline & 81 & 1 & 3,2 & 3,3 & 40,0 \\
\hline & 82 & 2 & 6,5 & 6,7 & 46,7 \\
\hline
\end{tabular}

\begin{tabular}{lrrrrr}
\hline & 83 & 3 & 9,7 & 10,0 & 56,7 \\
\cline { 2 - 6 } & 84 & 2 & 6,5 & 6,7 & 63,3 \\
\cline { 2 - 6 } & 85 & 1 & 3,2 & 3,3 & 66,7 \\
\cline { 2 - 6 } & 86 & 4 & 12,9 & 13,3 & 80,0 \\
\cline { 2 - 6 } & 88 & 1 & 3,2 & 3,3 & 83,3 \\
\cline { 2 - 6 } & 89 & 2 & 6,5 & 6,7 & 90,0 \\
\cline { 2 - 6 } & 90 & 1 & 3,2 & 3,3 & 93,3 \\
\cline { 2 - 6 } & 91 & 1 & 3,2 & 3,3 & 96,7 \\
\cline { 2 - 6 } & Total & 30 & 96,8 & 100,0 & \\
\cline { 2 - 6 } Missing & System & 1 & 3,2 & & \\
\hline Total & \multicolumn{5}{c}{100,0} \\
\hline
\end{tabular}

Dari tabel 3 maka dapat diperoleh data Postes Perencanaan Karir Remaja dengan frekuensi jawaban siswa paling rendah 67 dan paling tinggi 93 dan jawaban yang paling banyak pada rentang interval 86 berjumlah 4 orang remaja. Selanjutnya dapat dilihat pada tabel frekuensi berikut

Tabel 4 Tabel Frekuensi Postes Perencanaan Karir

Statistics

posttest

\begin{tabular}{lrr}
\hline \multirow{N}{*}{} & Valid & 30 \\
\cline { 2 - 3 } & Missing & 1 \\
\hline Mean & 81,57 \\
\hline Median & 83,00 \\
\hline Std. Deviation & 6,668 \\
\hline Variance & 44,461 \\
\hline Minimum & 67 \\
\hline Maximum & 93 \\
\hline Sum & 2447 \\
\hline
\end{tabular}

Dari tabel 4 diperoleh data perhitungan statistik tentang Postes Perencanaan Karir pada remaja di Kelurahan Dalan Lidang Kecamatan Panyabungan Kabupaten Mandailing Natal, sebanyak 30 orang dengan jumlah 26 item. Jumlah total dari skor Postes $=\mathbf{2 4 4 7}$, dengan skor tertinggi 93 dan skor terendah 67. Perhitungan mean $=81,57$, median 83,00, Standar deviasi $=6,668$. Dari data perhitungan statistik di atas dapat dibuat histogram sebagai berikut : 
Histogram Postes Perencanaan Karir

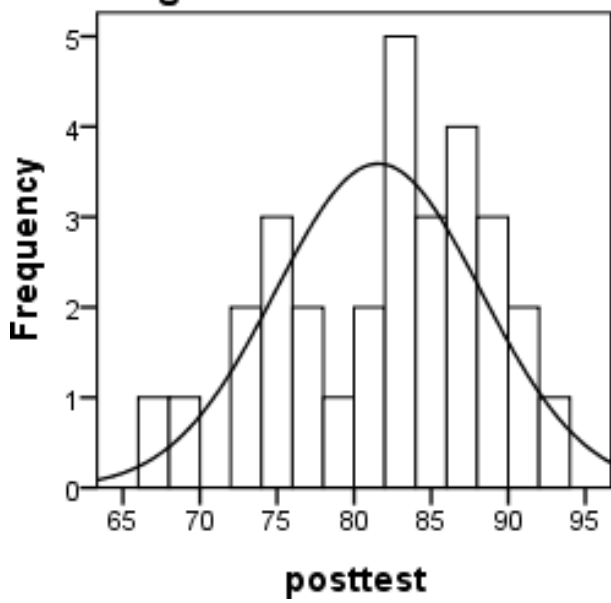

Gambar 2 Histogram Postes Perencanaan Karir

Dari histogram pada gambar 4.2 dapat diketahui bahwa data berdistribusi normal, karena sebahagian diagram batang berada dibawah kurva normal, sehingga dapat dikatakan data berditribusi normal

\section{B. Pengujian Persyaratan Analisis}

\section{Uji Normalitas}

\section{a. Uji normalitas data Pretes Perencanaan}

Karir

Untuk uji normalitas data pretes dapat dilihat pada tabel 5 berikut

Tabel 5 Hasil Uji Normalitas Data Pretes Perencanaan Karir

Tests of Normality

\begin{tabular}{|c|c|c|c|c|c|}
\hline & \multicolumn{3}{|c|}{$\begin{array}{c}\text { Kolmogorov- } \\
\text { Smirnov }^{\mathrm{a}}\end{array}$} & \multicolumn{2}{|c|}{ Shapiro-Wilk } \\
\hline & Statistic & $d f$ & Sig. & Statistic & Sig \\
\hline Pretest & , 157 & 30 & ,056 & ,921 & 30,02 \\
\hline
\end{tabular}

a. Lilliefors Significance Correction

Dari hasil analisis data pada tabel 5 diketahui bahwa signifikan 0,029 sedangkan nilai $\alpha=0,05$, sehingga $0,29<0,05$ Jadi dapat disimpulkan bahwa data pada pretes Perencanaan Karir berdistribusi normal dan untuk mengetahui bahwa data pretes perencanaan karir berdidtribusi normal, dapat
Perencanaan Karir berdistribusi normal.

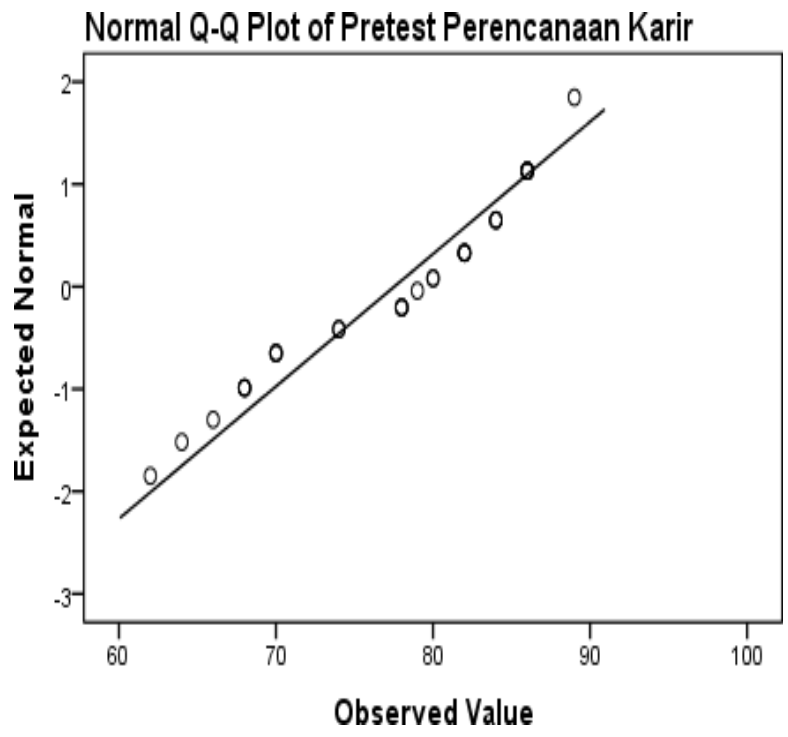

Gambar 3 Normal Plot Pretes Perencanaan Karir

\section{b. Uji normalitas data Postes Perencanaan Karir}

Untuk uji normalitas data Angket postes Perencanaan Karir dapat dilihat pada tabel 6 berikut.

Tabel 6 Hasil uji Normalitas Data Postes Perencanaan Karir

Tests of Normality

\begin{tabular}{lrrrrrr}
\hline & \multicolumn{3}{c}{$\begin{array}{c}\text { Kolmogorov- } \\
\text { Smirnov }\end{array}$} & \multicolumn{3}{c}{ Shapiro-Wilk } \\
& \multicolumn{1}{c}{ Statistic } & df & Sig. & Statistic & df & Sig. \\
\hline posttest &, 126 & $30^{, 200}$ & &, 966 & 30 &, 428
\end{tabular}

\footnotetext{
${ }^{*}$. This is a lower bound of the true significance.

a. Lilliefors Significance Correction
}

Dari hasil analisis data pada tabel 6 tersebut diketahui bahwa signifikan 0,428 sedangkan nilai $\alpha=0,05$, sehingga $0,428>$ 0,05 Jadi dapat disimpulkan bahwa data pada dilihat pada gambar 3 bahwa plot-plot mengikuti garis fit line, maka pretes 
postes Perencanaan Karir berdistribusi normal, dan untuk mengetahui bahwa data postes perencanaan karir berdidtribusi normal, dapat dilihat pada gambar 4.4 bahwa plot-plot mengikuti garis fit line, maka postes Perencanaan Karir berdistribusi normal. 


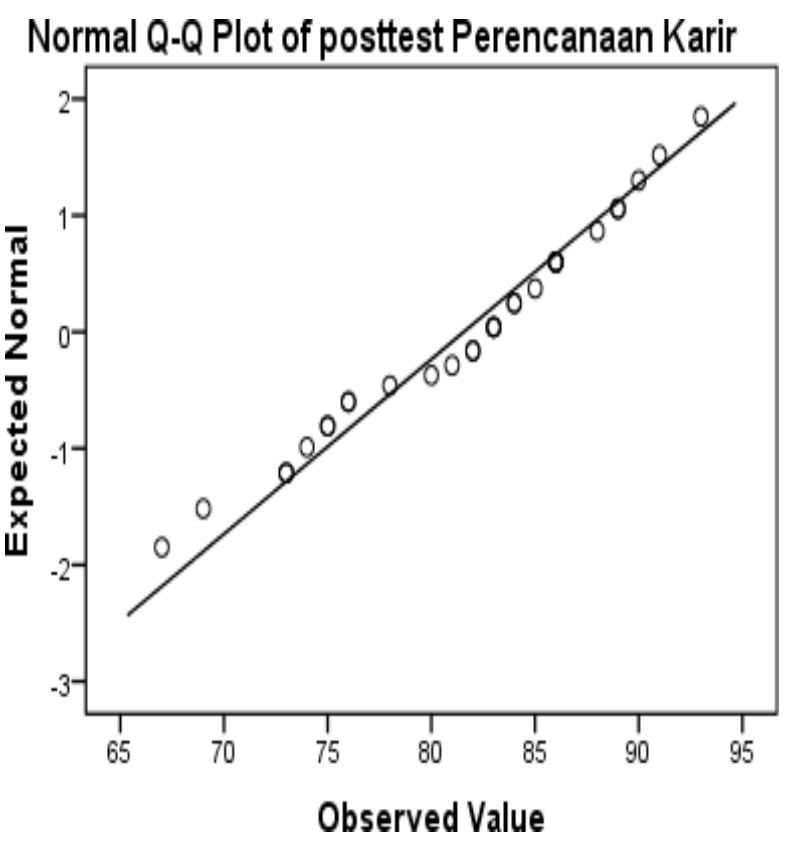

Gambar 4 Normal Plot Postes Perencanaan Karir

\section{Uji Homogenitas}

Untuk menguji apakah kedua kelompok homogen, akan diuji hipotesis sebagai berikut :

Tabel 7 Perhitungan Uji Homogenitas

\begin{tabular}{lccccc}
\hline & $\begin{array}{c}\text { Sum of } \\
\text { Squares }\end{array}$ & df & $\begin{array}{c}\text { Mean } \\
\text { Square }\end{array}$ & F & Sig. \\
\hline $\begin{array}{l}\text { Between } \\
\text { Groups }\end{array}$ & 1248,783 & 12 & 5 & 43,592 &, 000 \\
Within & & & 5,06 & \\
Groups & 40,583 & 17 & 2,387 & & \\
\hline Total & 1289,367 & 29 & & & \\
\hline
\end{tabular}

Dari perhitungan pada tabel 7 diperoleh $F_{\text {hitung }}=43,592$ dan nilai signifikan 0,00 Berdasarkan $\alpha=0,05$, maka nilai $0,00<0,05$ sehingga disim- pulkan bahwa data Pretes Perencanaan Karir dan Postes Perencanaan Karir adalah homogen.
Tabel 8 Uji Linieritas Layanan Informasi dan Perencanaan Karir

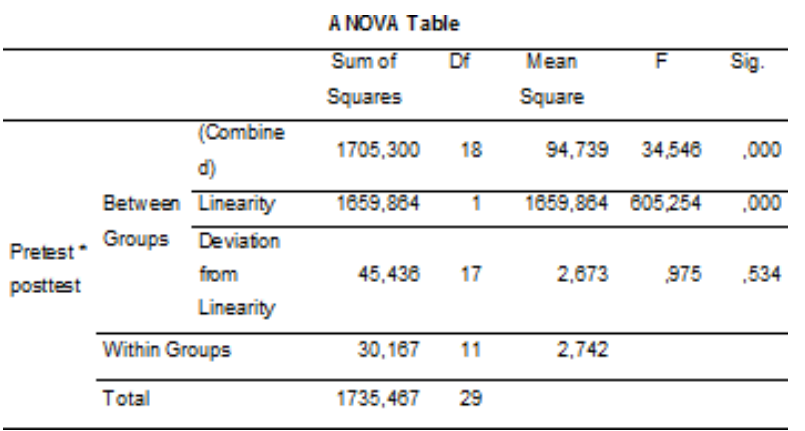

Dari Tabel 8 di atas dapat dilihat bahwa Signifikannya $0,534>0,05$, maka kedua variable linier, dan nilai $F$ hitung adalah 0,975 , sedangkan F tabel dapat dilihat pada df 10,372, maka $F$ tabel adalah 614,747, sehingga berdasarkan $\mathrm{F}$ hitung > F tabel Maka terdapat linieritas yang signifikan Layanan Informasi dan Perencanaan Karir. Sedangkan Nilai Signifikan adalah 0,975, berarti 0,975 >0,05 sehingga kedua variabel dinyatakan normal.

\section{Uji Hipotesis}

Pengujian hipotesis menggunakan uji statistika t. Uji ini digunakan untuk menguji hipotesis apakah kebenarannya dapat diterima atau ditolak.

Tabel 9 Perhitungan Pengaruh Layanan Informasi Terhadap Perencanaan Karir

\begin{tabular}{|c|c|c|c|c|c|c|}
\hline \multicolumn{7}{|c|}{ One-Sample Test } \\
\hline & \multirow[t]{2}{*}{$t$} & \multirow[t]{2}{*}{ df } & \multirow[t]{2}{*}{$\begin{array}{r}\text { Sig. } \\
(2- \\
\text { tailed })\end{array}$} & \multirow[t]{2}{*}{$\begin{array}{c}\text { Mean } \\
\text { Differen } \\
\text { ce }\end{array}$} & \multicolumn{2}{|c|}{$\begin{array}{l}95 \% \text { Confidence } \\
\text { Interval of the } \\
\text { Difference }\end{array}$} \\
\hline & & & & & Lower & Upper \\
\hline Pretest & 54,896 & 29 & 000 & 77,533 & 74,64 & 80,42 \\
\hline posttest & $\overline{67,001}$ & $\overline{29}$ &, 000 & 81,567 & 79,08 & 84.06 \\
\hline
\end{tabular}




\section{Uji Linearitas data Pretes Perencanaan} Karir dan Postes Perencanaan Karir

Berdasarkan hasil analisis yang dilakukan untuk Linearitas Pretes Perencanaan Karir dan Postes Perencanaan Karir, diperoleh nilai signifikansi variabel seperti tabel 8 berikut.

Dari hasil perhitungan uji t maka dapat dilihat bahwa pada pretes diperoleh uji $\mathrm{t}=$ 54,896 sedangkan setelah diberi perlakuan layanan Informasi maka diperoleh nilai uji $\mathrm{t}=$ 67.001, maka dengan diberikan layanan Informasi terhadap remaja maka Perencanaan Karir remaja meningkat sehingga dapat dikatakan bahwa terdapat pengaruh layanan Informasi terhadap Perencanaan Karir Remaja

di Kelurahan Dalan Lidang Kecamatan Panyabungan Kabupaten Mandailing Natal.

\section{Pembahasan dan Diskusi Hasil Penelitian}

Setelah penulis selesai mengolah semua data melalui tabulasi data, maka berikut ini penulis akan menganalisis data sebagai berikut:

Sesuai dengan penjabaran hasil-hasil di atas maka diperoleh nilai signifikan 0,00 dan hipotesis ini telah dicantumkan bahwa: Terdapat pengaruh Layanan Informasi Terhadap Perencanaan Karir Remaja di Kelurahan Dalan Lidang Kecamatan Panyabungan Kabupaten Mandailing Natal.

Dalam penelitian Saiful Rizal (2017:53) bahwa, perhitungan dalam pengujian hipotesis Berdasarkan hasil analisa data dari tabel uji $t$ test menunjukkan nilai $\mathrm{t}$ hitung sebesar 10,724 dengan taraf signifikan 5\% dan $\mathrm{db}=28$ ternyata besarnya angka batas penolakan hipotesis Nol yang dinyatakan dalam tabel distribusi $t$ adalah 2,048. Kenyataan ini menunjukkan bahwa nilai t hitung lebih besar dari $\mathrm{t}$ tabel $(10,724>2,048)$. Karna $\mathrm{t}$ hitung lebih besar dari $\mathrm{t}$ tabel maka penilitian ini dikatakan signifikan. Hal ini berarti bahwa hipotesis Nol (Ho)"ditolak" dan hipotesis alternatif (Ha) "diterima", maka dapat ditarik kesimpulan bahwa : Ada pengaruh layanan informasi terhadap perencanaan karir pada siswa kelas XI MA Darul Aitam Jerowaru Lombok Timur tahun pelajaran 2016/2017.

Sedangkan Menurut pendapat Sugiyono (2010: 254) "Karena t hitung $>\mathrm{t}$ tabel maka Ha diterima dan Ho ditolak" Maka dalam penelitian yang dilakukan oleh penulis diperoleh harga $\mathrm{t}$ hitung > t tabel yaitu 67,001

$>$ 2,045 maka Ho ditolak dan Ha diterima yaitu terdapat," Terdapat pengaruh layanan informasi terhadap perencanaan karir remaja di Kelurahan Dalan Lidang Kecamatan Panyabungan Kabupaten Mandailing Natal”.

\section{KESIMPULAN}

Berdasarkan uraian-uraian dari hasil penelitian yang telah dilakukan maka diperoleh kesimpulan sebagai berikut: Pretes Perencanaan Karir mempunyai rata-rata 77,53 dan standard deviasi 7,736 Sedangkan postes mempunyai rata- rata 81,57 dan standard deviasi 6,668 sehingga diperoleh t hitung 67,001. Dari hasil uji $\mathrm{t}$ dengan nilai postes 67,001 $>2,045$ sehingga dapat dikatakan bahwa hipotesis yang diajukan penulis dapat diterima maka dari itu $\mathrm{Ha}=$ diterima dan $\mathrm{Ho}=$ ditolak, sehingga uji hipotesis dapat terbukti yaitu terdapat pengaruh Layanan Informasi Terhadap Perencanaan Karir Remaja di KelurahanDalan Lidang Kecamatan Panyabungan Kabupaten Mandailing Natal.

\section{DAFTAR PUSTAKA}

Hurlock, E.B. 2009. Psikologi Perkembangan (Suatu Pendekatan Sepanjang Rentang Kehidupan) Edisi ke Lima. Terjemahan Istiwidayanti dan Soedjarwo. Tanpa Tahun. Jakarta: Erlangga.

Luddin, M.. 2012. Konseling Individual Dan Kelompok Aplikasi Dalam Praktek Konseling, Bandung: Citapustaka Media Perintis. 
Nengsih. 2019. Pengaruh Self Efficacy Terhadap Perencanaan Arah Karier Siswa Sma Dan Implikasinya Dalam Pelayanan Bimbingan Konseling. AlIrsyad: Jurnal Pendidikan dan Konseling, Vol. 9, No. 1.

Prayitno dan Amti, Erman. 2010. DasarDasar Bimbingan Dan Konseling, . Jakarta: Rineka Cipta.

Purwoko, Budi. 2008. Organisasi dan Managemen Bimbingan Konseling. Surabaya: Unes University Press.

Saiful Rizal. 2017. Pengaruh Layanan Informasi Terhadap Perencanaan Karir Pada Siswa Kelas XI MA Darul Aitam Jerowaru Lombok Timur tahun pelajaran 2016/2017. Jurnal. 
Sudjana, Nana. 2003. Penilaian Hasil Proses Belajar Mengajar. Bandung : PT. Remaja Rosdakarya.

Sugiyono. 2010. Metode Penelitian Pendidikan, cet ke 11 Bandung: Alfabeta.

Tohirin. 2013. Bimbingan Dan Konseling Di Sekolah Dan Madrasah, Jakarta: Raja Grafindo Persada.

Walgito, Bimo. 2005. Bimbingan Dan Konseling, Yogyakarta: Renika Cipta. 